\title{
Preparation, Spectroscopic Characterization, Thermal Stability and XRD of Some New Metal Chelates with Aceclofenac in Presence of 1,10-Phenanthroline
}

\author{
S.A. Sadeek ${ }^{1 *}$, S.F. Mohammed ${ }^{1}$, N.G. Rashid ${ }^{2}$ \\ ${ }^{1}$ Department of Chemistry, Faculty of Science, Zagazig University, Zagazig, Egypt. \\ ${ }^{2}$ National Center for Construction laboratories, Baghdad, Iraq.
}

\begin{abstract}
TN THIS study, mixed ligand complexes derived from aceclofenac (Acecl) as primary ligand and 1,10-phenanthroline (Phen) as secondary ligand have been prepared and characterized by conventional techniques including elemental analyses, infrared, electronic spectra, ${ }^{1} \mathrm{H} N \mathrm{NM}$ and XRD. The infrared spectral data showed that the chelation behavior of the ligands towards $\mathrm{Ni}(\mathrm{II}), \mathrm{Cu}(\mathrm{II}), \mathrm{Zn}(\mathrm{II}), \mathrm{Zr}(\mathrm{IV})$ and $\mathrm{La}(\mathrm{III})$ transition metal ions through oxygen of ketone, carboxylic group of aceclofenac and nitrogen atoms of 1,10-phenanthroline. Thermal analyses showed that the chelates lose water molecules of hydration initially and subsequently expel anionic part and organic ligands in continuous steps leaving metal or metal oxide as a final product. XRD analysis of the compounds showed that, Acecl, Phen and their metal complexes display crystalline peaks.
\end{abstract}

Keywords: Aceclofenac, Phen, Infrared spectral, XRD.

\section{Introduction}

Aceclofenac is a non-steroidal anti-inflammatory drug (NSAID) whose efficacy is offset by significant incidence of gastrointestinal ulceration which is a major side effect of most of the NSAIDs (Scheme 1). This ulceration is associated in part with the presence of carboxylic acid functionality in its structure. This functionality which is commonly found in the NSAIDs is unionized in the highly acidic environment of the stomach. As a result, these agents are more lipophilic in nature and may pass into the cells of the gastric mucosa. The intracellular $\mathrm{pH}$ of these cells is more basic than that of the stomach lumen and the NSAID becomes ionized. This results in back flow of protons from the lumen into these cells with concomitant cellular damage. This type of damage can be prevented if the carboxylic acid function could be eliminated from these agents. However, this functional group is a mandatory requirement for the anti-inflammatory activity [1-3].

Phen (Scheme 2) is a heterocyclic organic compound. It is a white solid that is soluble in organic solvents and may be prepared by two successive Skraup reactions of glycerol with o-phenylenediamine, catalyzed by sulfuric acid and an oxidizing agent, traditionally aqueous arsenic acidornitrobenzene. Dehydration of glycerol<smiles>O=C(O)COC(=O)Cc1ccccc1Nc1c(Cl)cccc1Cl</smiles>

Scheme 1. Structure of aceclofenac (Acecl).



Scheme 2. The structure of 1, 10phenanthrolinemonohydrate (Phen).

*Corresponding author e-mail: s_sadeek@zu.edu.eg.

Tel.: +20 01220057510; fax: +20 0553208213.

DOI: 10.21608/EJCHEM.2018.3856.1334

C2017 National Information and Documentation Center (NIDOC) 
gives acrolein which condenses with the amine followed by cyclization.

1, 10-phenanthroline is an attractive ligand due to its ability to act as strong binder for double-stranded DNA and facilitate the hydrogen atom abstraction from the sugar unit [4].1,10,-Phenanthroline (Phen) has been examined as a corrosion inhibitor for mild steel in $1 \mathrm{~N} \mathrm{H}_{2} \mathrm{SO}_{4}$ acid solution by weight-loss and gasometric methods [5].

\section{Experimental}

\section{Materials and Methods}

Chemicals

All chemicals used for preparation of the complexes were of analytical reagent grade, commercially available from different sources and used without further purification. Aceclofenacused in this study was purchased from Obour Pharmaceutical Industrial Company. 1,10-phenanthroline monohydrate, acetone, $\mathrm{NaOH}, \mathrm{ZrO}\left(\mathrm{NO}_{3}\right)_{2}(99.9 \%), \mathrm{Zn}\left(\mathrm{CH}_{3} \mathrm{COO}\right)_{2} \cdot 2 \mathrm{H}_{2} \mathrm{O}$, $\mathrm{Cu}\left(\mathrm{CH}_{3} \mathrm{COO}\right)_{2} \cdot \mathrm{H}_{2} \mathrm{O}, \quad \mathrm{Ni}\left(\mathrm{CH}_{3} \mathrm{COO}\right)_{2} \cdot 4 \mathrm{H}_{2} \mathrm{O}$ and $\mathrm{LaCl}_{3} .7 \mathrm{H}_{2} \mathrm{O}$ from Aldrich Chemical Co. All the chemicals and solvents were used as purchased without further purification.CHN analysis was carried on a Perkin Elmer CHN 2400. The percentages of the metal ions were determined gravimetrically by transforming the solid products into metal ion. The percentages of the metal ions were also estimated using an atomic absorption spectrometer. The spectrometer model was PYEUNICAMSP 1900 and fitted with the corresponding lamp. IR spectra were recorded on FT-IR 460 PLUS (KBr discs) in the range from $4000-400 \mathrm{~cm}^{-}$ ${ }^{1} .{ }^{1} \mathrm{H}$ NMR spectra were recorded on a Bruker 300 $\mathrm{MHz}$ NMR Spectrometer using tetramethylsilane (TMS) as the internal standard, chemical shifts are expressed in $\delta(\mathrm{ppm})$ and DMSO- $d_{6}$ was used as the solvent. Absorbance measurements were conducted on a double beam spectrophotometer (T80 UV/Vis) with wavelength range $190 \mathrm{~nm}$ $1100 \mathrm{~nm}$, spectral bandwidth of $2 \mathrm{~nm}$. Magnetic measurements were carried out on a Sherwood scientific magnetic balance using Gouy balance using $\mathrm{Hg}\left[\mathrm{Co}(\mathrm{SCN})_{4}\right]$ as calibrate. All melting points are uncorrected and were determined on a Gallen Kamp electric melting point apparatus. Molar conductivities of the solutions of the ligand and metal complexes in DMSO with concentrations of $1 \times 10^{-3} \mathrm{M}$ were measured on CONSORT K410.

$$
\begin{aligned}
& \text { Synthesis } \\
& {\left[\mathrm{Zn}(\text { Acec })(\mathrm{Phen})\left(\mathrm{H}_{2} \mathrm{O}\right)_{2}\right]\left(\mathrm{CH}_{3} \mathrm{COO}\right)_{2} \cdot 3 \mathrm{H}_{2} \mathrm{O}}
\end{aligned}
$$

Egypt.J.Chem. Special Issue (2018) complex was prepared by adding $1 \mathrm{mmol}(0.2195$ g) of zinc(II) acetate dihydrate in $20 \mathrm{ml}$ acetone drop-wise to a stirred suspended solution $1 \mathrm{mmol}$ $(0.353 \mathrm{~g})$ of Acecl with $1 \mathrm{mmol}(0.056 \mathrm{~g}) \mathrm{KOH}$ and $1 \mathrm{mmol}(0.198 \mathrm{~g})$ Phen in $50 \mathrm{ml}$ acetone. The reaction mixture was refluxed for $8 \mathrm{~h}$. The dark red precipitate was filtered off, washed several times with acetone until the filtrate becomes clear and dried under vacuum over anhydrous $\mathrm{CaCl}_{2}$. The blue, pale green,white pink and pale pink $\left[\mathrm{Cu}(\right.$ Acec $\left.)(\mathrm{Phen})\left(\mathrm{H}_{2} \mathrm{O}\right)_{2}\right]\left(\mathrm{CH}_{3} \mathrm{COO}\right)_{2} \cdot 6 \mathrm{H}_{2} \mathrm{O}$, $\left[\mathrm{Ni}(\mathrm{Acec})(\mathrm{Phen})\left(\mathrm{H}_{2} \mathrm{O}\right)_{2}\right]\left(\mathrm{CH}_{3} \mathrm{COO}\right)_{2} \cdot 3 \mathrm{H}_{2} \mathrm{O}$, $\left[\mathrm{La}(\right.$ Acec $)($ Phen $\left.)\left(\mathrm{H}_{2} \mathrm{O}\right)_{2}\right] \mathrm{Cl}_{3} \cdot 9 \mathrm{H}_{2} \mathrm{O}$ and $[\mathrm{ZrO}$ (Acec) (Phen) $\left.\left(\mathrm{H}_{2} \mathrm{O}\right)\right]\left(\mathrm{NO}_{3}\right)_{2} \cdot 9 \mathrm{H}_{2} \mathrm{O}$ were prepared in a similar manner described above by using acetone as a solvent and $\mathrm{Cu}\left(\mathrm{CH}_{3} \mathrm{COO}\right)_{2} \cdot \mathrm{H}_{2} \mathrm{O}$, $\mathrm{Ni}\left(\mathrm{CH}_{3} \mathrm{COO}\right)_{2} \cdot 4 \mathrm{H}_{2} \mathrm{O}, \mathrm{LaCl}_{3} \cdot 7 \mathrm{H}_{2} \mathrm{O}$ and $\mathrm{ZrO}\left(\mathrm{NO}_{3}\right)_{2}$ in $1: 1: 1: 1$ molar ratio.

\section{$\underline{\text { Results and Discussion }}$}

New mononuclear complexes of $\mathrm{Ni}(\mathrm{II})$, $\mathrm{Cu}(\mathrm{II}), \mathrm{Zn}(\mathrm{II}), \mathrm{Zr}(\mathrm{IV})$ and $\mathrm{La}(\mathrm{III})$ ions with Acecl in presence of Phen were synthesized. Analytical data indicated that the complexes formed with 1:1 stoichiometry. The results of physical properties of the prepared complexes along with their elemental analysis are collected in Table 1. The complexes are stable in air and soluble in most common organic solvents. The molar conductance in DMF $\left(10^{-3} \mathrm{M}\right)$ at room temperature reveals the electrolytic nature of the metal complexes. Qualitative reactions also agree well with the molar conductance data which revealed the presence of chloride, nitrate and acetate ions as counter ions. The magnetic moment values of $\mathrm{Ni}(\mathrm{II})$ and $\mathrm{Cu}(\mathrm{II})$ complexes at room temperature are 3.2 and 2.25 B.M., respectively, which will consistence with octahedral geometry around $\mathrm{Ni}(\mathrm{II})$ and $\mathrm{Cu}(\mathrm{II})$ [6].

\section{FT-IR absorption spectra}

The significant infrared bands of the organic ligands (Acecl and Phen) and its metal complexes (Fig. 1) are listed in Table 8 and the following features can be pointed out: The medium strong intensity band due to $\mathrm{v}(\mathrm{OH})$ group appear in the spectra of the free Acecl at $3316 \mathrm{~cm}^{-1}$. For metal complexes spectra the peak found at 3395 $3445 \mathrm{~cm}^{-1}$ were assigned to $\mathrm{v}(\mathrm{OH})$ of water molecules. In the infrared spectra of Acecl and Phen, the bands at 1770, 1717 and $1586 \mathrm{~cm}^{-1}$, were assigned to the $v(\mathrm{COO})^{-}, v(\mathrm{C}=\mathrm{O})_{\text {ketone }}$ and $v(\mathrm{C}=\mathrm{N})$ vibration frequencies $[7,8]$. In complexes the band due to $v(\mathrm{COO})^{-}$disappeared, while 
$v(\mathrm{C}=\mathrm{O})_{\text {ketone }}$ was shifted to higher wavenumbers by $18-20 \mathrm{~cm}^{-1}$ upon complexation denoting its coordination to metal ions. The $v(\mathrm{C}=\mathrm{N})$ of Phen was shifted to lower values $\left(46-76 \mathrm{~cm}^{-1}\right)$. The new bands appear in the region $1595-1575 \mathrm{~cm}^{-1}$ can be assigned to the asymmetric stretching vibration $\left(v_{a s}\right)$ of the ligated carboxylato group and the symmetric vibration occurs in the region $1340-1377 \mathrm{~cm}^{-1}$. The values of $\Delta v$ for our complexes are higher than $200 \mathrm{~cm}^{-1}$ indicating a monodentate coordination mode of the carboxylato group [9-12]. The coordination of the oxygen and nitrogen atoms of the ligands was supported by the appearance of new bands were observed at $656,528,477 \mathrm{~cm}^{-1}$ for $\mathrm{Ni}(\mathrm{II}), 721,662 \mathrm{~cm}^{-1}$ for $\mathrm{Cu}(\mathrm{II}), 657,573,529$ $\mathrm{cm}^{-1}$ for $\mathrm{Zn}(\mathrm{II}), 660,618,570,510 \mathrm{~cm}-1$ for $\mathrm{Zr}(\mathrm{IV})$ and 659, 634, 604, 570, 507, 474 for $\mathrm{La}(\mathrm{III})$ can be assigned to $\mathrm{v}(\mathrm{M}-\mathrm{O})$ and $\mathrm{v}(\mathrm{M}-\mathrm{N})$ respectively, confirming the coordination of both oxygen and nitrogen atoms to metal center [13]. The proposed structures for complexes are represented in Scheme 3. The data given in Table 8 show that $v(\mathrm{Zr}=\mathrm{O})$ is a medium band at $840 \mathrm{~cm}^{-1}$.

TABLE 1. Elemental analysis and physico-analytical data for aceclofenac (Acecl), 1,10-phenanthroline monohydrate (Phen) and their metal complexes.

\begin{tabular}{|c|c|c|c|c|c|c|c|c|c|c|}
\hline \multirow{2}{*}{$\begin{array}{l}\text { Compounds } \\
\text { M.Wt. (M.F.) }\end{array}$} & \multirow{2}{*}{$\begin{array}{c}\text { Yield } \\
\%\end{array}$} & \multirow{2}{*}{$\begin{array}{c}\text { Мp/ } \\
{ }^{\circ} \mathrm{C}\end{array}$} & \multirow{2}{*}{ Color } & \multicolumn{5}{|c|}{ Found (Calcd.) (\%) } & \multirow{2}{*}{$\begin{array}{c}\Lambda \\
\mathrm{S} \mathrm{cm}^{2} \\
\mathrm{~mol}^{-1}\end{array}$} & \multirow{2}{*}{$\begin{array}{c}\mu_{\text {eff }} \\
\text { (B.M.) }\end{array}$} \\
\hline & & & & $\mathbf{C}$ & $\mathbf{H}$ & $\mathbf{N}$ & M & Cl & & \\
\hline $\begin{array}{c}\text { Acecl } \\
389.4\left(\mathrm{C}_{18} \mathrm{H}_{20} \mathrm{FN}_{5} \mathrm{O}_{4}\right)\end{array}$ & - & 150 & White & $\begin{array}{r}55.45 \\
(55.47)\end{array}$ & $\begin{array}{l}5.12 \\
(5.14)\end{array}$ & $\begin{array}{l}17.95 \\
(17.98)\end{array}$ & - & - & 20.5 & - \\
\hline $\begin{array}{c}\text { Phen } \\
198.2\left(\mathrm{C}_{12} \mathrm{H}_{10} \mathrm{~N}_{2} \mathrm{O}\right)\end{array}$ & - & 100 & White & $\begin{array}{l}72.70 \\
(72.72)\end{array}$ & $\begin{array}{r}5.08 \\
(5.09)\end{array}$ & $\begin{array}{l}14.12 \\
(14.13)\end{array}$ & - & - & 5.0 & - \\
\hline $\begin{array}{c}{\left[\mathrm{Ni}(\text { Acec })(\mathrm{Phen})\left(\mathrm{H}_{2} \mathrm{O}\right)_{2}\right]} \\
\mathrm{CH}_{3} \mathrm{COO} .3 \mathrm{H}_{2} \mathrm{O} \\
775.69\left(\mathrm{NiC}_{32} \mathrm{H}_{40} \mathrm{FN}_{7} \mathrm{O}_{11}\right)\end{array}$ & 78.08 & 145 & $\begin{array}{l}\text { Pale } \\
\text { green }\end{array}$ & $\begin{array}{r}49.48 \\
(49.50)\end{array}$ & $\begin{array}{l}5.13 \\
(5.16)\end{array}$ & $\begin{array}{l}12.60 \\
(12.63)\end{array}$ & $\begin{array}{c}7.56 \\
(7.57)\end{array}$ & - & 85.20 & 3.2 \\
\hline $\begin{array}{c}{\left[\mathrm{Cu}(\text { Acec })(\mathrm{Phen})\left(\mathrm{H}_{2} \mathrm{O}\right)_{2}\right]} \\
\mathrm{CH}_{3} \mathrm{COO} .6 \mathrm{H}_{2} \mathrm{O} \\
834.54\left(\mathrm{CuC}_{32} \mathrm{H}_{46} \mathrm{FN}_{7} \mathrm{O}_{14}\right)\end{array}$ & 80.04 & 114 & Blue & $\begin{array}{r}46.00 \\
(46.01)\end{array}$ & $\begin{array}{r}5.49 \\
(5.51)\end{array}$ & $\begin{array}{l}11.71 \\
(11.74)\end{array}$ & $\begin{array}{r}7.60 \\
(7.61)\end{array}$ & - & 80.80 & 2.25 \\
\hline $\begin{array}{c}{\left[\mathrm{Zn}(\text { Acec })(\mathrm{Phen})\left(\mathrm{H}_{2} \mathrm{O}\right)_{2}\right]} \\
\mathrm{CH}_{3} \mathrm{COO} .3 \mathrm{H}_{2} \mathrm{O} \\
782.4\left(\mathrm{ZnC}_{32} \mathrm{H}_{40} \mathrm{FN}_{7} \mathrm{O}_{11}\right)\end{array}$ & 72.53 & 110 & $\begin{array}{c}\text { Dark } \\
\text { red }\end{array}$ & $\begin{array}{r}48.05 \\
(49.08)\end{array}$ & $\begin{array}{r}5.09 \\
(5.11)\end{array}$ & $\begin{array}{l}12.50 \\
(12.53)\end{array}$ & $\begin{array}{l}8.33 \\
(8.36)\end{array}$ & - & 83.40 & - \\
\hline $\begin{array}{c}{\left[\mathrm{ZrO}(\text { Acec })(\mathrm{Phen})\left(\mathrm{H}_{2} \mathrm{O}\right)\right]} \\
\mathrm{NO}_{3} .9 \mathrm{H}_{2} \mathrm{O} \\
917.22\left(\mathrm{ZrC}_{30} \mathrm{H}_{47} \mathrm{FN}_{8} \mathrm{O}_{18}\right)\end{array}$ & 89.35 & 150 & $\begin{array}{l}\text { Pale } \\
\text { pink }\end{array}$ & $\begin{array}{c}39.22 \\
(39.25)\end{array}$ & $\begin{array}{c}5.10 \\
(5.12)\end{array}$ & $\begin{array}{c}12.19 \\
(12.21)\end{array}$ & $\begin{array}{c}9.94 \\
(9.95)\end{array}$ & - & 90.10 & - \\
\hline $\begin{array}{c}{\left[\mathrm{La}(\text { Acec })(\mathrm{Phen})\left(\mathrm{H}_{2} \mathrm{O}\right)_{2}\right]} \\
\mathrm{Cl}_{2} \cdot 9 \mathrm{H}_{2} \mathrm{O} \\
975.79 \\
\left(\mathrm{LaC}_{30} \mathrm{H}_{49} \mathrm{FN}_{7} \mathrm{O}_{16} \mathrm{Cl}_{2}\right)\end{array}$ & 76.11 & 105 & $\begin{array}{l}\text { White } \\
\text { pink }\end{array}$ & $\begin{array}{c}36.87 \\
(36.89)\end{array}$ & $\begin{array}{c}5.00 \\
(5.02)\end{array}$ & $\begin{array}{c}10.02 \\
(10.04)\end{array}$ & $\begin{array}{c}14.23 \\
(14.24)\end{array}$ & $\begin{array}{c}7.25 \\
\text { (7.27) }\end{array}$ & 165.40 & - \\
\hline
\end{tabular}




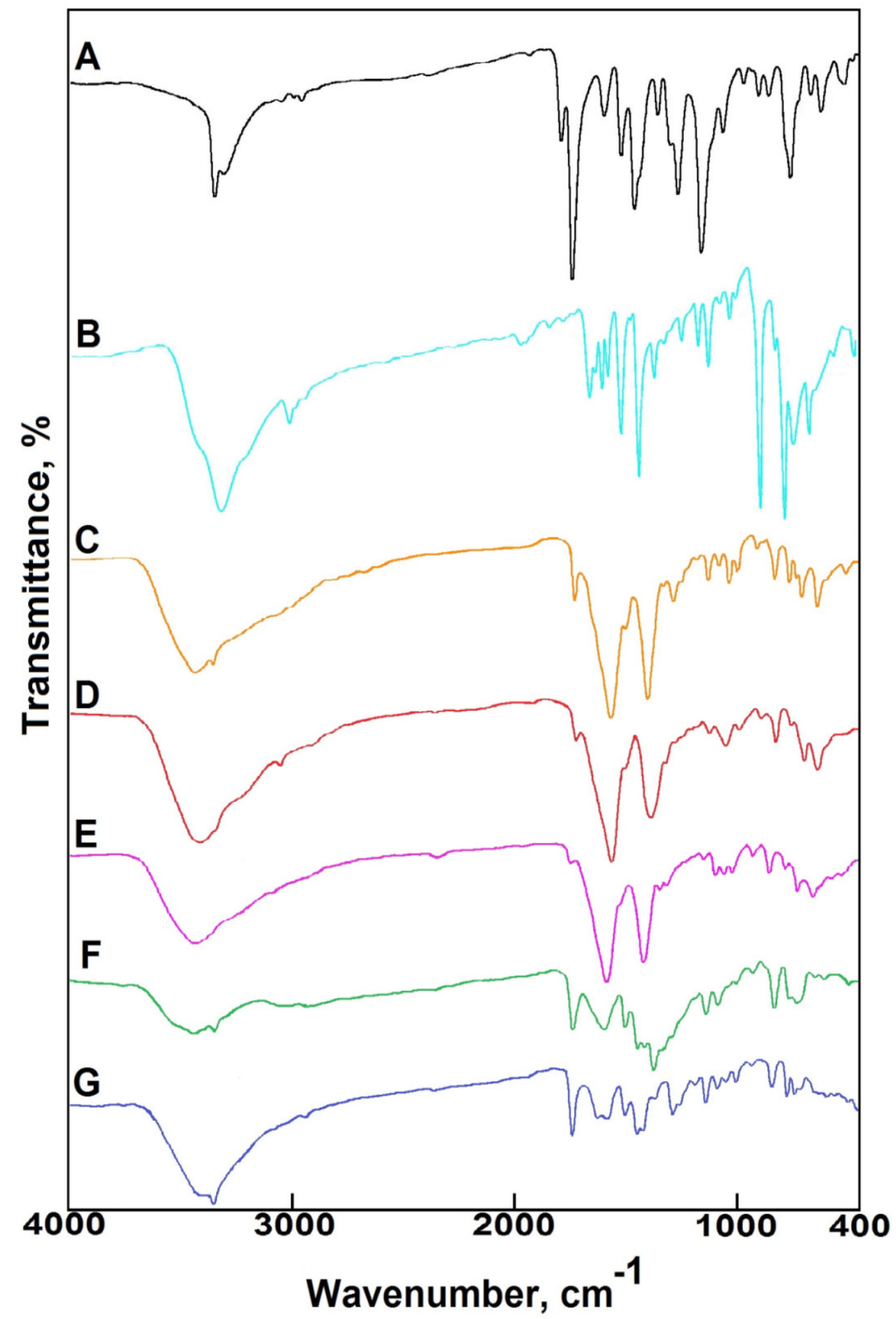

Fig. 1. Infrared spectra for(A) Acecl, (B) Phen, (C) $\left[\mathrm{Ni}(\mathrm{Acec})(\mathrm{Phen})\left(\mathrm{H}_{2} \mathrm{O}\right)_{2}\right] \mathrm{CH}_{3} \mathrm{COO} .3 \mathrm{H}_{2} \mathrm{O}$, (D) $[\mathrm{Cu}(\mathrm{Acec})$ $\left.(\mathrm{Phen})\left(\mathrm{H}_{2} \mathrm{O}\right)_{2}\right] \mathrm{CH}_{3} \mathrm{COO} .6 \mathrm{H}_{2} \mathrm{O},(\mathrm{E})\left[\mathrm{Zn}(\mathrm{Acec})(\mathrm{Phen})\left(\mathrm{H}_{2} \mathrm{O}\right)_{2}\right] \mathrm{CH}_{3} \mathrm{COO} .3 \mathrm{H}_{2} \mathrm{O}$, (F) [ $\mathrm{ZrO}($ Acec $\left.)(\mathrm{Phen})\left(\mathrm{H}_{2} \mathrm{O}\right)\right]$ $\mathrm{NO}_{3} .9 \mathrm{H}_{2} \mathrm{O}$ and $(\mathrm{G})\left[\mathrm{La}(\mathrm{Acec})(\mathrm{Phen})\left(\mathrm{H}_{2} \mathrm{O}\right)_{2}\right] \mathrm{Cl}_{2} .9 \mathrm{H}_{2} \mathrm{O}$. 


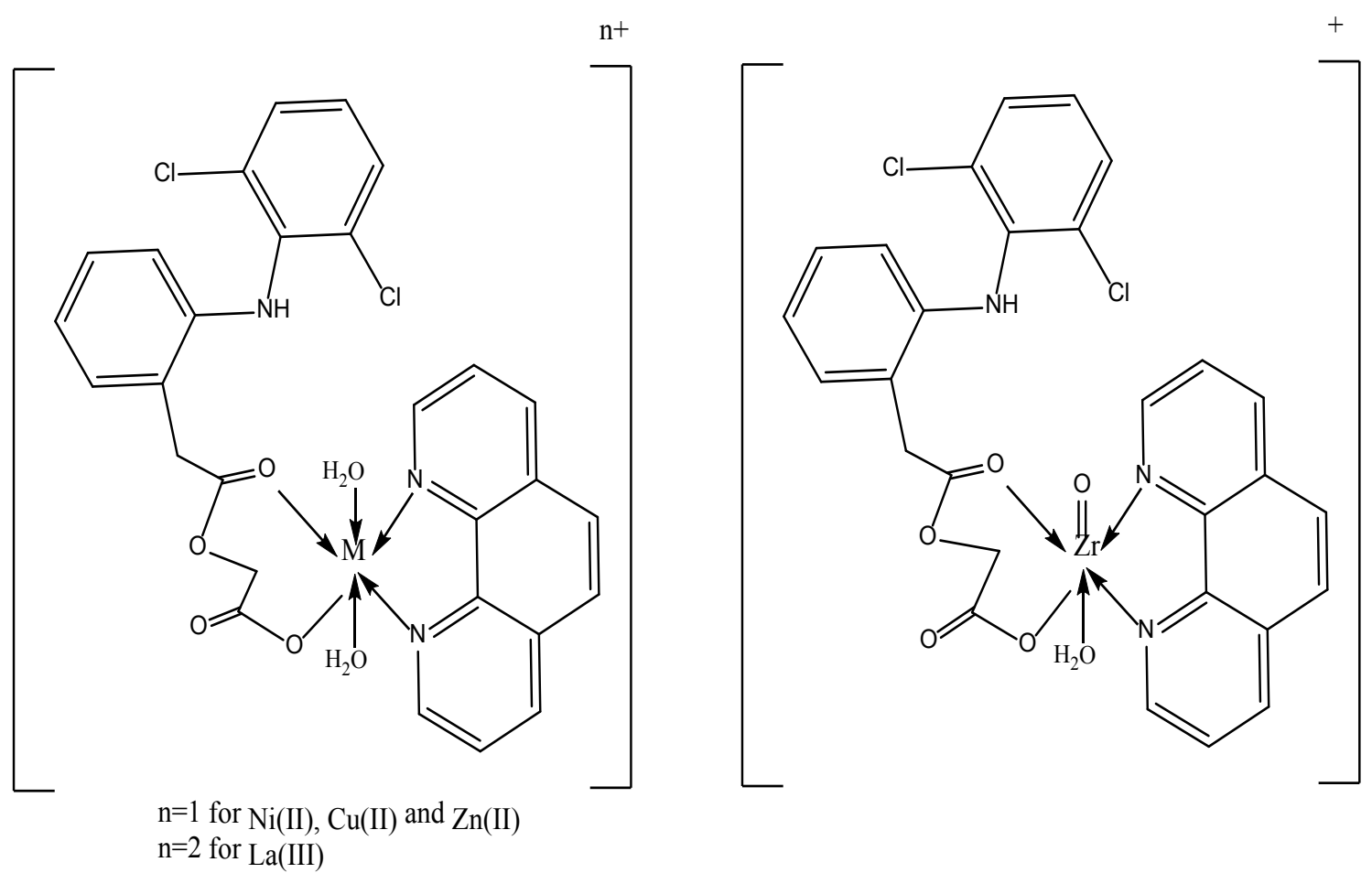

Scheme 3. The coordination mode of $\mathrm{Ni}(\mathrm{II}), \mathrm{Cu}$ (II) and $\mathrm{Zn}(\mathrm{II}), \mathrm{Zr}(\mathrm{IV})$ and $\mathrm{La}$ (III) with Acecl and Phen.

TABLE 2. Selected infrared absorption frequencies $\left(\mathrm{cm}^{-1}\right)$ of Acecl, Phen and their metal complexes.

\begin{tabular}{|c|c|c|c|c|c|c|c|c|}
\hline Compounds & $\begin{array}{c}\text { v(O-H); } \\
\mathrm{H}_{2} \mathrm{O} ; \\
\mathrm{COOH}\end{array}$ & $\begin{array}{c}\mathbf{v}(\mathrm{C}=\mathbf{O}) ; \\
\mathrm{COOH}\end{array}$ & $v(C=O)$ & $v_{\text {as }}\left(\mathrm{COO}^{-}\right)$ & $v(C=N)$ & $v_{s}\left(\mathrm{COO}^{-}\right)$ & $\begin{array}{c}\mathbf{v} \\
(\mathrm{Zr}=\mathrm{O})\end{array}$ & $\begin{array}{c}\mathrm{v}(\mathrm{M}-\mathrm{O}) \text { and } \\
\mathrm{v}(\mathrm{M}-\mathrm{N}) \\
\end{array}$ \\
\hline Aceclofenac & $3316 \mathrm{~ms}$ & $1770 \mathrm{~m}$ & $1717 \mathrm{vs}$ & - & - & - & - & - \\
\hline Phen & $3380 \mathrm{mbr}$ & - & - & - & $1586 \mathrm{~ms}$ & - & - & - \\
\hline $\begin{array}{c}{[\mathrm{Ni}(\text { Acec })} \\
\left.(\mathrm{Phen})\left(\mathrm{H}_{2} \mathrm{O}\right)_{2}\right] \\
\mathrm{CH}_{3} \mathrm{COO} .3 \mathrm{H}_{2} \mathrm{O}\end{array}$ & $3432 \mathrm{mbr}$ & & $1737 \mathrm{~m}$ & $1575 \mathrm{~s}$ & $1513 \mathrm{vw}$ & $1342 \mathrm{vw}$ & - & $\begin{array}{c}656 \mathrm{~m}, 528 \mathrm{vw} \\
477 \mathrm{vw}\end{array}$ \\
\hline $\begin{array}{c}{[\mathrm{Cu}(\text { Acec })} \\
\left.(\mathrm{Phen})\left(\mathrm{H}_{2} \mathrm{O}\right)_{2}\right] \\
\mathrm{CH}_{3} \mathrm{COO} .6 \mathrm{H}_{2} \mathrm{O}\end{array}$ & $3421 \mathrm{mbr}$ & & $1737 w$ & $1581 \mathrm{~s}$ & $1521 \mathrm{vw}$ & $1341 \mathrm{vw}$ & - & $721 \mathrm{w}, 662 \mathrm{~m}$ \\
\hline $\begin{array}{c}{[\mathrm{Zn}(\text { Acec })} \\
\left.(\mathrm{Phen})\left(\mathrm{H}_{2} \mathrm{O}\right)_{2}\right] \\
\mathrm{CH}_{3} \mathrm{COO} .3 \mathrm{H}_{2} \mathrm{O}\end{array}$ & $3427 \mathrm{mbr}$ & & $1736 \mathrm{vw}$ & $1577 \mathrm{vs}$ & 1520 sh & $1340 w$ & - & $\begin{array}{c}657 \mathrm{w}, 573 \mathrm{vw} \\
529 \mathrm{vw}\end{array}$ \\
\hline $\begin{array}{c}{[\mathrm{ZrO}(\text { Acec })} \\
\left.(\mathrm{Phen})\left(\mathrm{H}_{2} \mathrm{O}\right)\right] \\
\mathrm{NO}_{3} \cdot 9 \mathrm{H}_{2} \mathrm{O}\end{array}$ & $3445 \mathrm{mbr}$ & & $1735 \mathrm{~ms}$ & $1595 \mathrm{~ms}$ & $1511 \mathrm{~ms}$ & $1377 \mathrm{~s}$ & $840 \mathrm{~ms}$ & $\begin{array}{l}660 \mathrm{vw}, 618 \mathrm{vw} \\
570 \mathrm{vw}, 510 \mathrm{vw}\end{array}$ \\
\hline $\begin{array}{l}{[\mathrm{La}(\text { Acec })(\text { Phen })} \\
\left.\left(\mathrm{H}_{2} \mathrm{O}\right)_{2}\right] \mathrm{Cl}_{2} \cdot 9 \mathrm{H}_{2} \mathrm{O}\end{array}$ & $3395 \mathrm{mbr}$ & & $1736 \mathrm{~ms}$ & $1585 \mathrm{~m}$ & $1510 w$ & $1366 w$ & - & $\begin{array}{c}659 \mathrm{vw}, 634 \mathrm{vw}, \\
604 \mathrm{vw}, 570 \mathrm{vw}, \\
507 \mathrm{w}, 474 \mathrm{vw}\end{array}$ \\
\hline
\end{tabular}

Keys: $\mathrm{s}=$ strong, $\mathrm{w}=$ weak, $\mathrm{m}=$ medium, br=broad, $v=$ stretching. 


\section{$U V$-Vis. spectra}

In order to get information about the hyperdization and configuration of the complexes, the electronic spectra of the complexes were measured. UV-Visible spectral data of the free Acecl, Phen ligands and their complexes were recorded from 200 to $800 \mathrm{~nm}$ as shown in Fig. 2. The absorption spectra of the free Acecl exhibited high intensity bands at 225, $240 \mathrm{~nm}$ and 266, $278 \mathrm{~nm}$ (Table 3 ) which may be assigned to $\pi-\pi^{*}$ and $n-\pi *$ transitions, respectively $[14,15]$. Also, Phenshows bands at $243 \mathrm{~nm}$ and 273, $350 \mathrm{~nm}$ which may be assigned to $\pi-\pi^{*}$ and $n-\pi^{*}$ transitions, respectively. The shift of the absorption bands to higher or lower and appearance of new bands for the complexes is attributed to complexation
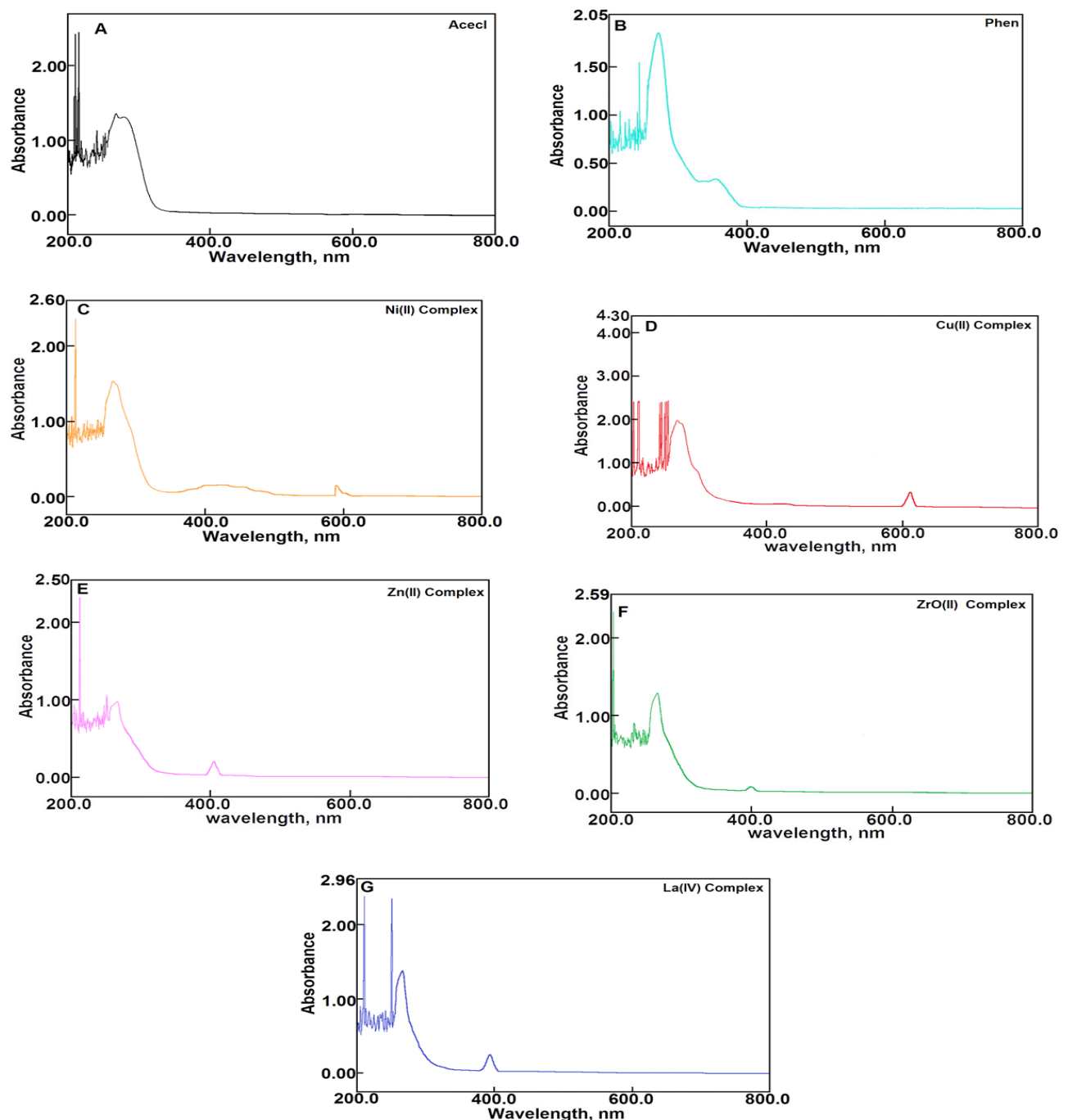

Fig. 2. Electronic absorption spectra for(A) Acecl, (B) Phen, (C) $\left[\mathrm{Ni}(\mathrm{Acec})(\mathrm{Phen})\left(\mathrm{H}_{2} \mathrm{O}\right)_{2}\right] \mathrm{CH}_{3} \mathrm{COO}_{2} \mathrm{H}_{2} \mathrm{O}$, (D) $\left[\mathrm{Cu}(\right.$ Acec $\left.)(\mathrm{Phen})\left(\mathrm{H}_{2} \mathrm{O}\right)_{2}\right] \mathrm{CH}_{3} \mathrm{COO} .6 \mathrm{H}_{2} \mathrm{O}$, (E) [Zn(Acec)(Phen) $\left.\left(\mathrm{H}_{2} \mathrm{O}\right)_{2}\right] \mathrm{CH}_{3} \mathrm{COO}_{3} \mathrm{H}_{2} \mathrm{O}$, (F) [ZrO(Acec) $\left.(\mathrm{Phen})\left(\mathrm{H}_{2} \mathrm{O}\right)\right] \mathrm{NO}_{3} \cdot 9 \mathrm{H}_{2} \mathrm{O}$ and $(\mathrm{G})\left[\mathrm{La}(\mathrm{Acec})(\mathrm{Phen})\left(\mathrm{H}_{2} \mathrm{O}\right)_{2}\right] \mathrm{Cl}_{2} .9 \mathrm{H}_{2} \mathrm{O}$.

Egypt.J.Chem. Special Issue (2018)

of mixed ligand. Also the complexes of $\mathrm{Ni}(\mathrm{II})$, $\mathrm{Cu}(\mathrm{II}), \mathrm{Zn}(\mathrm{II}), \mathrm{Zr}(\mathrm{IV})$ and $\mathrm{La}(\mathrm{III})$ show new bands in the range 393-426 nm, which may be assigned to ligand-metal charge transfer [1619]. The electronic spectrum of the binuclear nickel(II) complex showed two bands, the first band occurs at $565 \mathrm{~nm}$ which is corresponding to the ${ }^{3} \mathrm{~A}_{2 \mathrm{~g}} \rightarrow{ }^{3} \mathrm{~T}_{1 \mathrm{~g}}(\mathrm{P})$ electronic transition. The other band occurs at $615 \mathrm{~nm}$ which is corresponding to the ${ }^{3} \mathrm{~A}_{2 \mathrm{~g}} \rightarrow{ }^{3} \mathrm{~T}_{1 \mathrm{~g}}(\mathrm{~F})$ electronic transition. The two transitions are consistent with an octahedral geometry of the complex [20,21]. The d-d transition absorption spectra for $\mathrm{Cu}$ (II) complex shows one absorption band at $620 \mathrm{~nm}$ which are assigned to ${ }^{2} \mathrm{~B}_{1}$ of octahedral geometry [22]. 
TABLE 3. UV-Vis. spectra of Acecl, Phen, Ni(II), $\mathrm{Cu}(\mathrm{II}), \mathrm{Zn}(\mathrm{II}), \mathrm{Zr}(\mathrm{IV})$ and $\mathrm{La}(\mathrm{III})$ complexes.

\begin{tabular}{|c|c|c|c|c|c|c|c|}
\hline \multirow[b]{2}{*}{ Assignments (nm) } & \multirow[b]{2}{*}{ Acecl } & \multirow[b]{2}{*}{ Phen } & \multicolumn{5}{|c|}{ Mixed ligand complex with } \\
\hline & & & $\mathrm{Ni}(\mathrm{II})$ & $\mathrm{Cu}(\mathrm{II})$ & $\mathrm{Zn}(\mathrm{II})$ & $\mathrm{Zr}(\mathrm{IV})$ & La(III) \\
\hline$\pi-\pi^{*}$ transitions & $\begin{array}{l}225 \\
240\end{array}$ & 243 & 245 & 250 & 238 & 230 & $\begin{array}{l}233 \\
250\end{array}$ \\
\hline $\mathrm{n}-\pi^{*}$ transitions & $\begin{array}{l}266 \\
278\end{array}$ & $\begin{array}{l}273 \\
350\end{array}$ & 267 & 267 & 265 & 265 & 265 \\
\hline Ligand-metal charge transfer & - & - & 426 & 420 & 402 & 400 & 393 \\
\hline d-d transition & - & - & $\begin{array}{l}565 \\
615\end{array}$ & 620 & - & - & - \\
\hline
\end{tabular}

\section{${ }^{1} H$ NMR spectra}

Proof of the bonding type of the ligands is also confirmed by comparing the ${ }^{1} \mathrm{H}$ NMR spectra of the ligands in normal DMSO- $d_{6}$, at room temperature deuterated solvent and their complexes. The chemical shifts of the various types of protons in the ${ }^{1} \mathrm{H}$ NMR spectra of the ligands and their complexes are givens in Table 4 . In the aromatic region, a few doublets and in few cases some overlapping doublets/ multiblets are observed in the range $\delta \sim 6.21$ $9.24 \mathrm{ppm}$ due to the protons of benzene ring. Another singlet corresponding to one proton for Acecl is observed at 13.11 and $2.51 \mathrm{ppm}$. It can be assigned either to $\mathrm{OH}$ of carboxylic group or $\mathrm{NH}$. The signal of $\mathrm{OH}$ disappeared in all metal complexes. The ${ }^{1} \mathrm{H}$ NMR spectra for all complexes exhibit new signal in the range 3.79$3.93 \mathrm{ppm}$, due to presence of water molecules in the complexes [23-25]. On comparing Acecl with its complexes, all signals of the free ligand are present in spectra of the complexes with some shifts from binding of the ligand to the metal (Fig. 3).

\section{$X$-ray diffraction}

The powder XRD patterns of Acecl, Phen,Ni(II), $\mathrm{Cu}(\mathrm{II}), \mathrm{Zn}(\mathrm{II}), \mathrm{Zr}(\mathrm{IV})$ andLa(III) complexes were recorded over $2 \theta$ in the range scale (10-70) as shown in Fig. 4. The diffraction of Acecl, shows four sharp diffraction peaks at about $2 \theta\left[\mathrm{d}\right.$ value $\left.\mathrm{A}^{\circ}\right]=25.96$ [3.43], 22.25 [3.99], 19.43 [4.57] and 17.52 [5.06]. The diffraction of Phen, shows three sharp diffraction peaks at about $2 \theta\left[\mathrm{d}\right.$ value $\left.\mathrm{A}^{\circ}\right]=$ 19.87 [4.47], 22.43 [3.96] and 17.22 [5.15].
The diffractogram of $\mathrm{Ni}(\mathrm{II})$ complex indicated main peaks at $2 \theta\left[\mathrm{d}\right.$ value $\left.\mathrm{A}^{\circ}\right]=15.99[5.54]$, $32.20[2.78], 26.01[3.43]$ and 15.66[5.66]. The XRD patterns of $\mathrm{Cu}(\mathrm{II})$ complex exhibited sharp peaks corresponding to $2 \theta$ [d value $\left.\mathrm{A}^{\circ}\right]=8.08[10.93], 24.17[3.68], 10.77[8.22]$, 15.97[5.55], 11.50[7.70] and 32.39[2.76]. The $\mathrm{x}$-ray powder diffraction for $\mathrm{Zn}(\mathrm{II})$ complex give six sharp peaks at $2 \theta\left[\mathrm{d}_{\text {value }} \mathrm{A}^{\circ}\right]=11.88[7.45]$, 10.65[8.31], 25.95[3.43], 32.64[2.74], $27.02[3.30]$ and 21.38[4.16]. The diffraction of $\mathrm{Zr}(\mathrm{IV})$ complex give five sharp peaks at $2 \theta\left[\mathrm{d}\right.$ value $\left.\mathrm{A}^{\circ}\right]=25.80[3.45], 10.61[8.34]$, 9.13[9.69], 15.36[5.77] and 21.31[4.17]. The XRD patterns of $\mathrm{La}(\mathrm{III})$ complex give five peaks at $2 \theta\left[\mathrm{d}\right.$ value $\left.\mathrm{A}^{\circ}\right]=28.39$ [3.14], 12.18[7.27], 25.97[3.43], 16.50[5.37] and 23.88[3.73]. The mean crystallite sizes, estimated using Scherer equation [26-28], are shown in Table 5. The data in this table clarify that, Acecl, Phen and their metal complexes display crystalline peaks.

\section{Conclusion}

Aceclofenac (Acecl) in presence of 1,10-phenanthroline monohydrate (Phen) reacts with $\mathrm{Ni}(\mathrm{II}), \mathrm{Cu}(\mathrm{II}), \mathrm{Zn}(\mathrm{II}), \mathrm{Zr}(\mathrm{IV})$ and $\mathrm{La}$ (III) in acetone to form solid complexes by 1:1:1:1 molar ratios (metal: Acecl: Phen: $\mathrm{KOH}$ ). These complexes characterized by elemental analyses, IR, UV-Vis., 1H NMR spectra, XRD diffraction, molar conductance and magnetic susceptibility. The infrared spectra indicated that Acecl ligand is bound to metal ions via ketone oxygen and one carboxylate oxygen, where chelation occurs also through pyridyl nitrogen of Phen. 
TABLE 4. ${ }^{1} \mathrm{H}$ NMR values (ppm) and tentative assignments for (A) Acecl, (B) Phen, (C) [Ni(Acec)(Phen) $\left.\left(\mathrm{H}_{2} \mathrm{O}\right)_{2}\right] \mathrm{CH}_{3} \mathrm{COO} .3 \mathrm{H}_{2} \mathrm{O}$, (D) $\left[\mathrm{Cu}(\mathrm{Acec})(\mathrm{Phen})\left(\mathrm{H}_{2} \mathrm{O}\right)_{2}\right] \mathrm{CH}_{3} \mathrm{COO} .6 \mathrm{H}_{2} \mathrm{O}$, (E) $\left[\mathrm{Zn}(\right.$ Acec $\left.)(\mathrm{Phen})\left(\mathrm{H}_{2} \mathrm{O}\right)_{2}\right]$ $\mathrm{CH}_{3} \mathrm{COO} .3 \mathrm{H}_{2} \mathrm{O},(\mathrm{F})\left[\mathrm{ZrO}(\mathrm{Acec})(\mathrm{Phen})\left(\mathrm{H}_{2} \mathrm{O}\right)\right] \mathrm{NO}_{3} .9 \mathrm{H}_{2} \mathrm{O}$ and $(\mathrm{G})\left[\mathrm{La}(\mathrm{Acec})(\mathrm{Phen})\left(\mathrm{H}_{2} \mathrm{O}\right)_{2}\right] \mathrm{Cl}_{2} .9 \mathrm{H}_{2} \mathrm{O}$.

\begin{tabular}{|c|c|c|c|c|c|c|c|}
\hline $\mathbf{A}$ & $\mathbf{B}$ & $\mathbf{C}$ & $\mathbf{D}$ & $\mathbf{E}$ & $\mathbf{F}$ & $\mathbf{G}$ & Assignments \\
\hline $2.50,2.51$ & - & 2.51 & 2.51 & $1.75-2.52$ & $1.92-2.51$ & $1.91-2.51$ & $\delta \mathrm{H},-\mathrm{NH}$ \\
\hline $3.37-4.65$ & - & $3.32-3.64$ & $3.17-3.65$ & $3.18-3.65$ & $3.40-3.65$ & $3.40-3.62$ & $\delta \mathrm{H}, ~^{-\mathrm{CH}_{2} \text { aliphatic }}$ \\
\hline- & - & $3.80-3.88$ & 3.81 & 3.82 & $3.82-3.90$ & $3.79-3.93$ & $\delta \mathrm{H}_{2} \mathrm{H}_{2} \mathrm{O}$ \\
\hline $6.27-7.54$ & $7.26-8.81$ & $6.24-7.72$ & $6.24-7.54$ & $6.25-9.13$ & $6.25-9.12$ & $6.21-9.24$ & $\delta \mathrm{H},-\mathrm{CH}$ aromatic \\
\hline 13.11 & - & - & - & - & - & - & $\delta \mathrm{H},-\mathrm{COOH}$ \\
\hline
\end{tabular}
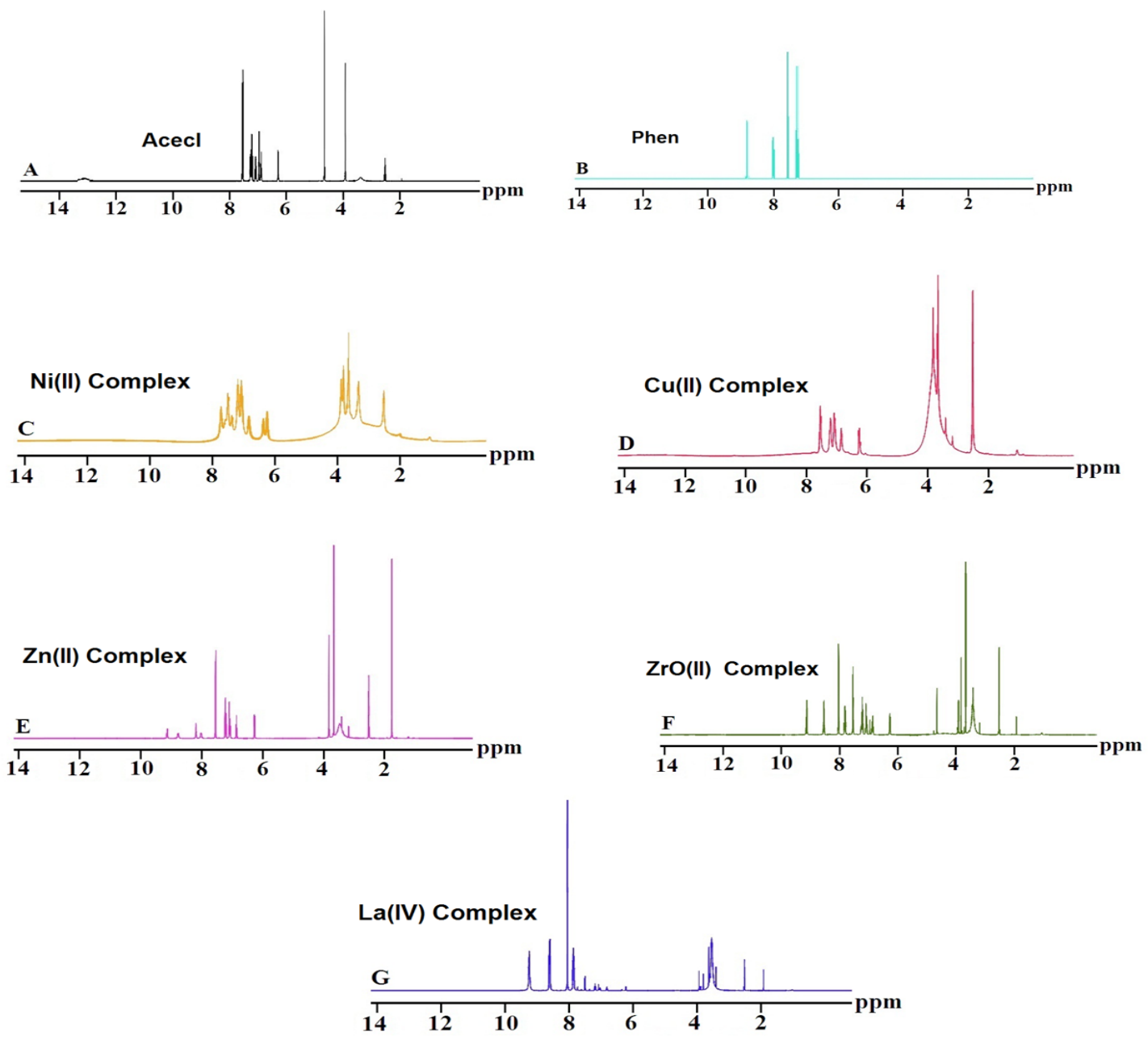

Fig. 3. 1H NMR spectra for (A) Acecl, (B) Phen, (C) [Ni(Acec)(Phen)( $\left.\left.\mathrm{H}_{2} \mathrm{O}\right)_{2}\right] \mathrm{CH}_{3} \mathrm{COO}_{3} \mathrm{H}_{2} \mathrm{O}$, (D) $[\mathrm{Cu}(\mathrm{Acec})$ $\left.(\mathrm{Phen})\left(\mathrm{H}_{2} \mathrm{O}\right)_{2}\right] \mathrm{CH}_{3} \mathrm{COO} .6 \mathrm{H}_{2} \mathrm{O},(\mathrm{E})\left[\mathrm{Zn}(\mathrm{Acec})(\mathrm{Phen})(\mathrm{H} 2 \mathrm{O})_{2}\right] \mathrm{CH}_{3} \mathrm{COO} .3 \mathrm{H}_{2} \mathrm{O}$, (F) [ ZrO(Acec)(Phen $\left.)\left(\mathrm{H}_{2} \mathrm{O}\right)\right]$ $\mathrm{NO}_{3} \cdot 9 \mathrm{H}_{2} \mathrm{O}$ and $(\mathrm{G})\left[\mathrm{La}(\right.$ Acec $)($ Phen $\left.)\left(\mathrm{H}_{2} \mathrm{O}\right)_{2}\right] \mathrm{Cl}_{2} \cdot \mathbf{9 H}_{2} \mathrm{O}$. 

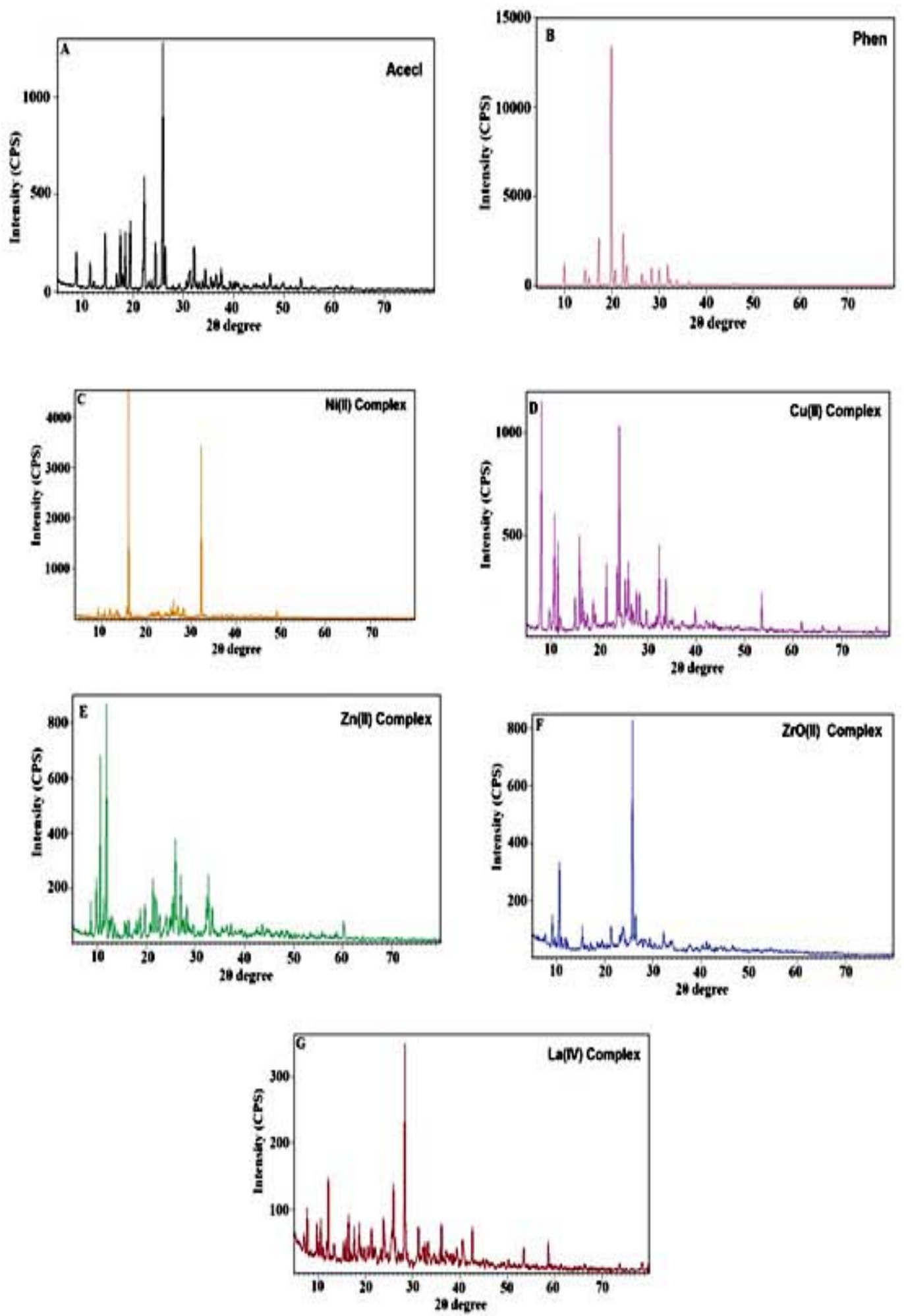

Fig. 4. Powder XRD pattern for (A) Acecl, (B) Phen,(C) $\left[\mathrm{Ni}(\mathrm{Acec})(\mathrm{Phen})\left(\mathrm{H}_{2} \mathrm{O}\right)_{2}\right] \mathrm{CH}_{3} \mathrm{COO} .3 \mathrm{H}_{2} \mathrm{O}$, (D) $[\mathrm{Cu}(\mathrm{Acec})$ $\left.(\mathrm{Phen})\left(\mathrm{H}_{2} \mathrm{O}\right)_{2}\right] \mathrm{CH}_{3} \mathrm{COO} .6 \mathrm{H}_{2} \mathrm{O}$, (E) $\left[\mathrm{Zn}(\mathrm{Acec})(\mathrm{Phen})\left(\mathrm{H}_{2} \mathrm{O}\right)_{2}\right] \mathrm{CH}_{3} \mathrm{COO} .3 \mathrm{H}_{2} \mathrm{O},(\mathrm{F})\left[\mathrm{ZrO}(\mathrm{Acec})(\mathrm{Phen})\left(\mathrm{H}_{2} \mathrm{O}\right)\right]$ $\mathrm{NO}_{3} .9 \mathrm{H}_{2} \mathrm{O}$ and $(\mathrm{G})\left[\mathrm{La}(\mathrm{Acec})(\mathrm{Phen})\left(\mathrm{H}_{2} \mathrm{O}\right)_{2}\right] \mathrm{Cl}_{2} .9 \mathrm{H}_{2} \mathrm{O}$. 
TABLE 5. The average crystallite size of Acecl, Phen and thier complexes estimated from XRD pattern.

\begin{tabular}{|c|c|c|c|c|c|}
\hline Compounds & $2 \theta\left(\left(^{\circ}\right)\right.$ & $\begin{array}{c}\text { d value } \\
\left(\mathrm{A}^{\circ}\right)\end{array}$ & $\begin{array}{c}\text { Relative } \\
\text { intensity } \\
(\%)\end{array}$ & $\begin{array}{l}\text { Full width } \\
\text { at half } \\
\text { maximum } \\
\text { (FWHM) }^{\mathrm{a}}\end{array}$ & $\begin{array}{c}\text { Average } \\
\text { crystallite size } \\
\text { (nm) }\end{array}$ \\
\hline Acecl & 25.96 & 3.43 & 100 & 0.074 & 37.59 \\
\hline Phen & 19.87 & 4.47 & 100 & 0.217 & 38.93 \\
\hline$\left[\mathrm{Ni}(\right.$ Acec $\left.)(\mathrm{Phen})\left(\mathrm{H}_{2} \mathrm{O}\right)_{2}\right] \mathrm{CH}_{3} \mathrm{COO} \cdot 3 \mathrm{H}_{2} \mathrm{O}$ & 15.99 & 5.54 & 100 & 0.186 & 60.06 \\
\hline$\left[\mathrm{Cu}(\right.$ Acec $\left.)(\mathrm{Phen})\left(\mathrm{H}_{2} \mathrm{O}\right)_{2}\right] \mathrm{CH}_{3} \mathrm{COO} \cdot 6 \mathrm{H}_{2} \mathrm{O}$ & 8.09 & 10.93 & 100 & 0.151 & 117.85 \\
\hline$\left[\mathrm{Zn}(\right.$ Acec $)($ Phen $\left.)\left(\mathrm{H}_{2} \mathrm{O}\right)_{2}\right] \mathrm{CH}_{3} \mathrm{COO} \cdot 3 \mathrm{H}_{2} \mathrm{O}$ & 11.88 & 7.45 & 100 & 0.115 & 16.61 \\
\hline$\left[\mathrm{ZrO}(\right.$ Acec $\left.)(\mathrm{Phen})\left(\mathrm{H}_{2} \mathrm{O}\right)\right] \mathrm{NO}_{3} \cdot 9 \mathrm{H}_{2} \mathrm{O}$ & 25.80 & 3.45 & 100 & 0.065 & 37.81 \\
\hline$\left[\mathrm{La}(\right.$ Acec $\left.)(\mathrm{Phen})\left(\mathrm{H}_{2} \mathrm{O}\right)_{2}\right] \mathrm{Cl}_{2} \cdot 9 \mathrm{H}_{2} \mathrm{O}$ & 28.39 & 3.14 & 100 & 0.092 & 34.55 \\
\hline
\end{tabular}

${ }^{a}$ The maximum diffraction patterns according to the highest value of intensity.

\section{References}

1. Block J.H. and Beale J.M., Organic Medicinal and Pharmaceutical Chemistry, $11^{\text {th }}$ ed.; Lippincott Williams \& Wilkins: New York (2004).

2. Kale M.A., Shelke R., Nawale R.B., ZincAceclofenac Complex: Synthesis, Hydrolysis Study and Antiinflammatory Studies, AntiInflammatory \& Anti-Allergy Agents in Medicinal Chemistry, 13, 36 (2014).

3. Shapiro J., effects of dexamethasone and cyclosporin A, J. Invest. Derma. Symp. Proc. 16, S42 (2013).

4. . HalcrowB.E and Kermack W.O., The preparation of styrene chlorohydrin, J. Chem. Soc. 43, 155 (1946).

5. Banerjee S.N. and Misra S., 1,10,-Phenanthroline as Corrosion Inhibitor for Mild Steel in Sulfuric Acid Solution, Corrosion, 45(9), 780 (1989).

6. Geary W.J., The use of conductivity measurements in organic solvents for the characterisation of coordination compounds, Coord. Chem. Rev., 7, 81 (1971).

7. Hu G.Q., Yang Y., Yi L., Wang X., Zhang Z.Q. and Xie S.Q., Design, synthesis and antitumor activities of fluoroquinolone C-3 heterocycles (IV): s-triazole Schiff-Mannich bases derived from ofloxacin, Acta Pharm. Sin., 45, 1012 (2010).

8. Hu G.Q., Yang Y., Yi L., Wang G.Q., Duan N.N., Wen X.Y., Cao T.Y., Xie S.Q. and Huang W.L., Design, synthesis and antitumor activities of

Egypt.J.Chem. Special Issue (2018) fluoroquinolone C-3 heterocycles (IV): S-triazole Schiff-Mannich bases derived from ofloxacin, Acta Pharm. Sin., 1, 172 (2011).

9. Wallis S.C., Gahan L.R., Charles B.G., Hambley T.W., 13C N.M.R. and Single-Crystal X-Ray Structural Investigation of the Fluoroquinolone Antimicrobial Drug Norfloxacin 2DCl.D 2 O, Aust. J. Chem., 47, 799 (1994).

10. Efthimiadou E.K., Katsaros N., Karaliota A. and Psomas G., Synthesis, characterization, antibacterial activity, and interaction with DNA of the vanadyl-enrofloxacin complex, Bioorg. Med. Chem. Lett., 17, 1238 (2007).

11. Efthimiadou E.K., Sanakis Y., Katsarou M., Raptopoulou C.P., Karaliota A., Katsaros N. and Psomas G., Neutral and cationic mononuclear copper(II) enrofloxacin: Structure and biological complexes with activity, J. Inorg. Biochem., 100, 1378 (2006).

12. Nakamoto K., Infrared and Raman Spectra of Inorganic and Coordination Compounds, $4^{\text {th }}$ ed., Wiley, New York, 230 (1986).

13. Cygler M., Huber C.P., Structure of oxolinic acid, a potent antibacterial agent. 1-Ethyl1,4-di-hydro-6,7-methylene-dioxy-4-oxo-3quinoline-carboxylic acid, $\mathrm{C}_{13} \mathrm{H}_{11} \mathrm{NO}_{5}$, Acta Crystallogr., C 41, 1052 (1985).

14. Refat M.S., Synthesis and characterization of norfloxacin-transition metal complexes (group 11, IB): Spectroscopic, thermal, kinetic measurements and biological activity, Spectrochim. Acta A, 68, 
1393 (2007).

15. Sultana N., Naz A., Arayne M.S., Mesaik M.A., Synthesis, characterization, antibacterial, antifungal and immunomodulating activities of gatifloxacin-metal complexes, J. Mol. Struct., 969, 17 (2010).

16. Sadeek S.A., Synthesis, thermogravimetric analysis, infrared, electronic and mass spectra of $\mathrm{Mn}(\mathrm{II}), \mathrm{Co}(\mathrm{II})$ and $\mathrm{Fe}(\mathrm{III})$ norfloxacin complexes, J. Mol. Struct., 753, 1 (2005).

17. Cotton F.A., Wilkinson G., Murillo C.A. and Bochmann M., Advanced Inorganic Chemistry, $6^{\text {th }}$ ed., Wiley, New York, 1054 (1999).

18. Sadeek S.A., Refat M.S. and Hashem H.A., Complexation and thermogravimetric investigation on tin(II) and tin(IV) with norfloxacin as antibacterial agent, J. Coord. Chem., 59, 759 (2006).

19. Sadeek S.A. and EL-Shwiniy W.H., Metal complexes of the third generation quinolone antibacterial drug sparfloxacin: Preparation, structure, and microbial evaluation, J. Coord. Chem., 63, 3471 (2010).

20. Khalil S.M.E., Mashaly M.M. and Emara A.A.A., Copper(II), Nickel(II), Oxovanadium(IV) and Dioxouranium(VI) Complexes of Novel Asymmetric Tetradentate Schiff Base Ligands Derived from 6-Methyl-3-Formyl-4-Hydroxy-2(1H)-Quinolone. Part V, Synth. React. Inorg. Met. -Org. Chem., 25, 1373 (1995).

21. Shebl M., Synthesis, spectral and magnetic studies of mono- and bi-nuclear metal complexes of a new bis(tridentate NO2) Schiff base ligand derived from 4,6-diacetylresorcinol and ethanolamine, SpectrochimicaActa A, 73, 313 (2009).

22. Mondal N., Dey D.K., Mitra S. and Abdul Malik
K.M., Synthesis and structural characterization of mixed ligand $\eta 1$-2-hydroxyacetophenone complexes of cobalt(III), Polyhedron, 19, 2707 (2000).

23. El-Sonbati A.Z., Diab M.A., El-Bindary A.A., Eldesoky A.M. and Morgan S.M., Correlation between ionic radii of metals and thermal decomposition of supramolecular structure of azodye complexes., Spectrochim. Acta A, 135, 774 (2015).

24. El-Sonbati A.Z., Shoair A.F., El-Bindary A.A. and Mohamed A.S., Synthesis, characterization, DNA binding and catalytic activities of Ru(III) complexes, J. Mol. Liq. 209, 635 (2015).

25. El-Ghamaz N.A., El-Sonbati A.Z., Diab M.A., El-Bindary A.A., Awad M.K. and Morgan S.M., Dielectrical, conduction mechanism and thermal properties of rhodanineazodyes, Mater. Sci. Semicond. Process. 19, 150 (2014).

26. Ain Q., Pandey S.K., Pandey O.P. and Sengupta S.K., Synthesis, spectroscopic, thermal and antimicrobial studies of neodymium(III) and samarium(III) complexes derived from tetradentate ligands containing $\mathrm{N}$ and $\mathrm{S}$ donor atoms, Spectrochim. Acta A,140, 27 (2015).

27. Saad G.M., N-aminophthalimide as a synthon for heterocyclic Schiff bases: Efficient utilization as corrosion inhibitors of mild steel in 0.5 mol. $\mathrm{L}^{-1}$ $\mathrm{H}_{2} \mathrm{SO}_{4}$ solution, E.J.Chem., 61(3), 300 (2018).

28. Soliman A.M., Mohsen K., Ahmed F. E., Joanna W. and Magdalena M.,The Antiproliferative Activity and Molecular Docking studies of some sulfonamides against cancer cell lines compared to normal cells, E.J.Chem., 61(3), 330 (2018).

(Received 30/5/2018; accepted 15/7/2018)

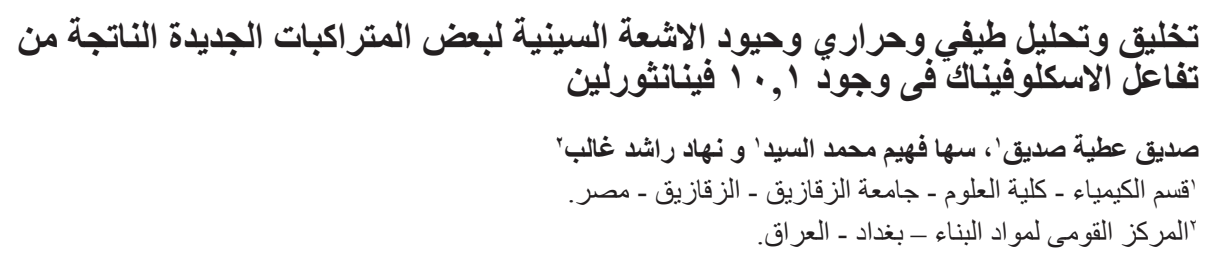

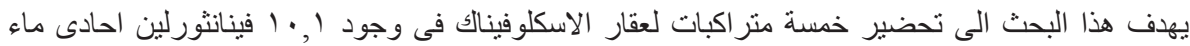

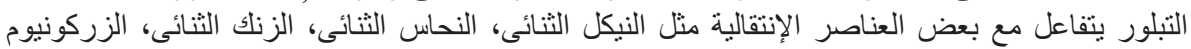

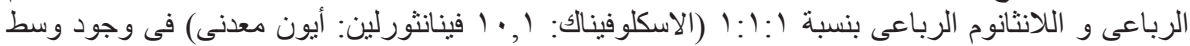

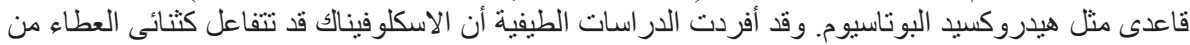

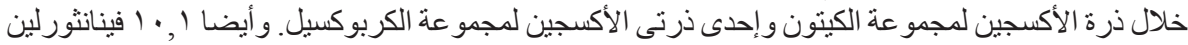

يتفاعل كثنائى العطاء من خلال ذرتى النتروجين لحلقتى البيردين.

Egypt.J.Chem. Special Issue (2018) 